\title{
Námsmat á yngsta stigi í skóla án aðgreiningar
}

\author{
Auður Lilja Harðardóttir og Jóhanna Karlsdóttir
}

\footnotetext{
Abstract Um höfundana About the authors $>$ Heimildir
}

Stefnan um skóla án aðgreiningar (e. inclusive education) hefur fengið mikla umfjöllun á undanförnum árum og ríkir óvissa um hvernig skuli innleiða hana svo vel takist til. Lykilhugtök stefnunnar eru vönduð menntun allra, fullgild pátttaka, jafngild tækifæri og lýðræðisleg gildi. Misvísandi hugmyndir um stefnuna geta haft áhrif á viðhorf og skilning kennara. Brýn nauðsyn er pess vegna að skilgreina hugtakið og skapa pví sameiginlegan pekkingarfræðilegan grundvöll innan skóla og utan. Greina má gjá (e. gap) í fræðunum par sem ekki hefur tekist að samræma námsmat og skóla án aðgreiningar. Námsmat er yfirgripsmikið hugtak en einn megintilgangur pess er að leiðbeina nemendum og örva pá í námi, vera peim hvatning og stuðla að námsvitund peirra. Vandað námsmat getur aukið pátttöku allra nemenda og ábyrgð peirra á eigin námi og haft jákvæð áhrif á vaxtarsjálf (e. growth mindset) peirra. Greininni er ætlað að skapa umræður í skólasamfélaginu um hvernig efla má skilning á málefninu.

Rannsóknin var viðtalsrannsókn og fór fram í fjórum grunnskólum í Kópavogi. Pátttakendur voru fimm grunnskólakennarar. Markmið hennar var að kanna hvernig námsmati umsjónarkennarar á yngsta stigi beita í skólum án aðgreiningar. Einnig voru stefnuskjöl sveitarfélagsins og grunnskóla pess greind.

Niðurstöður benda til pess að kennarar hafi jákvæð viðhorf til menntastefnunnar en telji aftur á móti að aukið fjármagn purfi til pess að auka skilvirkni hennar. Dátttakendur reyndust sýna góðan skilning á inntaki stefnunnar og kennsluhættir peirra einkenndust af pví að reyna að koma til móts við alla nemendur með fjölbreyttum kennsluaðferðum. Ósamræmi í starfsháttum peirra innbyrðis kom pó fram, einkum með tilliti til pess hvar nemendur með sérparfir voru staðsettir innan skóla og óvissa var um hver bæri ábyrgð á námi peirra. Pátttakendur reyndust meðvitaðir um mikilvægi fjölbreytts námsmats og beittu hefðbundnu og óhefðbundnu mati jöfnum höndum. Greina mátti misskilning pegar tilgang leiðsagnarmats bar á góma varðandi hvernig slíkt mat birtist í framkvæmd og víðtæk áhrif pess á nám.

Efnisorð: Skóli án aðgreiningar, námsmat, leiðsagnarmat, vaxtarsjálf

\section{Inngangur}

Umræðan um skóla án aðgreiningar er viðkvæm. Hún vekur von um betra og réttlátara samfélag en einkennist um leið af togstreitu og álitamálum. Hugmyndafræðin sem liggur að baki stefnunni er byggð á peim grundvallarmannréttindum að allir skuli eiga aðild að lýðræðislegu samfélagi. Skólar purfa pví að skapa rými til að jafna stöðu og rétt einstaklinga og draga úr aðgreiningu. 
Á Íslandi er skilningur margra á stefnunni sá að allir nemendur skuli fá stundað nám innan síns heimaskóla, óhád líkamlegu, andlegu eða félagslegu atgervi (Arthur Morthens og Gretar L. Marinósson, 2002). Hins vegar snýst skóli án aðgreiningar einnig um grundvallargildi eins og jafnrétti, félagslegt réttlæti og pátttöku allra nemenda í skólastarfi par sem peir fá jafngild tækifæri til náms, auk viðurkenningar á margbreytilegum nemendahópi samkvæmt Aðalnámskrá grunnskóla (Mennta- og menningarmálaráðuneytið, 2013).

Víða má greina gjá (e. gap) í fræðum par sem fjallað er um námsmat og skóla án aðgreiningar. Hér er annars vegar vísað til skilnings á námsmati og hins vegar einstaklingsbundnum pörfum nemenda og gjánni sem hefur myndast par á milli. Fram kemur í úttekt Evrópumiðstöðvar um sérkennslu og menntun án aðgreiningar að ekki hafi tekist að samræma námsmat og ólíkar parfir nemenda hér á landi (European agency for special needs and inclusive education, 2017). Af peim sökum má draga pá ályktun að skilgreina purfi betur hvaða námsmatsaðferðir séu best til pess fallnar að styðja skóla án aðgreiningar. Aðalnámskrá grunnskóla (Mennta- og menningarmálaráðuneytið, 2013) leggur ríka áherslu á notkun leiðsagnarmats. Рað byggist á að nemandi metur reglulega eigið nám í samstarfi við kennara, hvar hann er staddur og hvað hann parf að gera til að ná markmiðum sínum. Sú nýbreytni sem parna má greina er aukin pátttaka nemenda, sjálfstæði og ábyrgð á eigin námsferli (Mennta- og menningarmálaráđuneytið, 2013). Vísbendingar eru um að beiting leiðsagnarmats ýti undir aukna námsvitund nemenda (Earl, 2013) og próun vaxtarsjálfs (e. growth mindset), en pað vísar til hugmynda nemenda um eigin getu til aðgerða, p.e. að hún sé sveigjanleg og breytanleg. Peir verða viljugri að glíma við verðug verkefni sem færa peim aukinn proska og nemendur dafna í skólanum (Dweck, 2010; Kristján Kristjánsson, 2007, 2008).

Grein pessi byggist á meistaraverkefni sem gert var á vorönn 2017 í samstarfi annars höfundar við umsjónarkennara á yngsta stigi í fjórum grunnskólum í Kópavogi. Rannsóknin var ekki síður liður í pví að leyfa almennum umsjónarkennurum að tjá sig sem pátttakendur á vettvangi. Rannsóknin var eigindleg og byggðist á einstaklingsviðtölum við fimm umsjónarkennara á yngsta stigi. Rannsóknarspurningarnar sem leitað var svara við voru eftirfarandi: (1) Hvernig námsmati beita kennarar í fjölbreyttum nemendahópi í skóla án aðgreiningar? (2) Hvaða skilning leggja umsjónarkennarar í menntastefnuna skóli án aðgreiningar? (3) Hver eru viðhorf umsjónarkennara til námsmats í skóla án aðgreiningar?

Í greininni er fjallað um fræðilegan bakgrunn skóla án aðgreiningar og námsmat í fjölbreyttum nemendahópi. Dví næst er greint frá rannsóknaraðferðinni og niðurstöðum hennar og að lokum er umræða og ályktanir sem kviknuðu út frá henni. Tekið skal fram að tilgangur rannsóknarinnar er hvorki að meta né dæma störf kennara í pátttökuskólunum heldur að gefa innsýn í pau til að vekja áhuga á málefninu og skapa umræðu um námsmat í skóla án aðgreiningar.

\section{Skóli án aðgreiningar}

Skóli án aðgreiningar (e. inclusive education) er líklega mest notað sem lýsandi hugtak og hefur sem slíkt verið notað í menntastefnu flestra ríkja heims, en pað getur leitt til pess að merking pess er mismunandi frá einu landi til annars (Hermína Gunnpórsdóttir og Dóra S. Bjarnason, 2014; Ingólfur Ásgeir Jóhannesson, 2006a). Mismunandi merking í ólíku samhengi getur skapað ósamræmi og óvissu og leitt til erfiðleika við innleiðingu stefnunnar og framkvæmd. Í fjölmenningarsamfélagi birtist ósamræmið annars vegar í pví hvernig lönd takast á við skóla án aðgreiningar á ólíkan hátt og hins vegar í ólíkri hugtakanotkun sem miðast við reglugerðir, sögu og menningu hvers lands (Ainscow, 2005; Hermína Gunnpórsdóttir, 2014).

Ainscow, Booth og Dyson (2006) benda á að skóla án aðgreiningar megi skilgreina á marga vegu. Hugmyndafræði stefnunnar má skilgreina sem ferlishugsun og nálgun ákveðinna gilda. Slíkur skóli lætur sig varða alla nemendur og leitast við að sigrast á hvers kyns hindrunum í vegi náms sem fela í sér aðgreiningu, útilokun eða slakt námsgengi (Ainscow, Booth og Dyson, 2006; Booth og Ainscow, 2002). 
Í hugmyndinni um skóla án aðgreiningar felst pað markmið að veita öllum börnum viðeigandi gæðamenntun og stuðla að félagslegri blöndun og undirbúningi fyrir pátttöku í lýðræðislegu samfélagi (Arthur Morthens og Gretar L. Marinósson, 2002; Booth og Ainscow, 2002; Dóra S. Bjarnason, 2012).

Stefnan er byggð á rétti hvers barns til að stunda nám í almennu skólakerfi par sem nemendur purfa ekki að „,vinna“ fyrir leið sinni inn í skólastofuna með „réttri“ hegðun eða færni. Deir eru taldir fullgildir meðlimir, hugsanlega með aðlögun og sértækum stuðningi, en áhersla er lögð á fulla pátttöku peirra í öllu skólastarfi (Sapon-Shevin, 2007).

Hér og erlendis eru vaxandi áhyggjur af pví að sameiginlegan pekkingarfræðilegan bakgrunn skorti í allri umræðu um skóla án aðgreiningar (Ainscow, 2005; Hermína Gunnpórsdóttir og Ingólfur Ásgeir Jóhannesson, 2014). Í skýrslu Evrópumiðstöðvarinnar (European agency for special needs and inclusive education, 2017) kemur skýrt fram að skilgreina purfi hugtakið skóla án aðgreiningar betur á öllum stigum menntakerfisins á Íslandi, hjá öllum aðilum sem koma að menntamálum.

Til pess að auka sameiginlegan pekkingarfræðilegan skilning á hugtökum og markmiðum stefnunnar parf að skapa umræðuvettvang (European agency for special needs and inclusive education, 2017). Slíkur vettvangur byggist á samstarfi ólíkra aðila innan menntamála en vísbendingar eru um að fá tækifæri gefist til slíkra umræðna. Vinnuaðstæður og ósveigjanlegur vinnutími innan skóla teljast hindranir pegar kemur að faglegum umræðum um stefnuna og tækifærum kennara til að miðla reynslu sinni hver með öðrum. Detta hefur pau áhrif að peir einangrist í starfi í stað pess að skapa samvinnuvettvang um nám og kennslu í skóla án aðgreiningar (European agency for special needs and inclusive education, 2017).

Kennarar eru taldir lykilaðilar í próun skóla án aðgreiningar. Trú peirra, viðhorf og aðferðir skapa samhengi par sem börn og ungmenni purfa að læra. Með pað í huga snýst verkefnið um að próa menntakerfi par sem kennarar finna stuðning auk áskorana um ábyrgð peirra til að halda áfram að próa skilvirkari leiðir til að koma til móts við alla nemendur (Ainscow og Miles, 2008). Margir kennarar tala hins vegar um að pá skorti nægilega pekkingu, færni og viðhorf til að vinna í anda skóla án aðgreiningar (European agency for special needs and inclusive education, 2017; Ingólfur Ásgeir Jóhannesson, 2006b). Dó sýna niðurstöður úr rannsókn Hermínu Gunnpórsdóttur og Dóru S. Bjarnason (2014) um viðhorf kennara til skóla án aðgreiningar að kennarar töldu sig ekki skorta faglega pekkingu. Frekar mætti rekja vandann til ytri aðstæðna á borð við námskrá, skort á stuðningi og kröfur sem hindruðu og höfðu áhrif á starfshætti peirra. Detta eru dæmi um mismunandi sjónarmið sem geta skapast út frá ólíkum skilgreiningum og aðstæðum á vettvangi.

\section{Námsmat}

Lög um grunnskóla (nr. 91/2008) segja að tilgangur námsmats sé að fylgjast með pví hvernig nemendum tekst að mæta hæfniviðmiðum aðalnámskrár og eigin námsmarkmiðum, örva nemendur til framfara og meta hverjir purfi á sérstakri aðstoð að halda. Núgildandi Aðalnámskrá grunnskóla (Mennta- og menningarmálaráðuneytið, 2013) segir enn fremur að megintilgangur námsmats sé að leiðbeina nemendum um námið og hvernig peir geti náð markmiðum pess. Ekki er tekið sérstaklega fram hvernig námsmati skuli háttað svo par sé tekið mið af pörfum og getu allra nemenda, heldur segir að taka purfi tillit til sérparfa nemenda og sértækra örðugleika peirra (Mennta- og menningarmálaráðuneytið, 2013).

Margt bendir til ákveðinnar togstreitu í notkun námsmats í skólastarfi nú á dögum. Pannig virðist ríkja visst ráđaleysi pegar námsmat er annars vegar. Meyvant Dórólfsson, Ingvar Sigurgeirsson og Jóhanna Karlsdóttir (2009) telja að ráðaleysið megi rekja til pversagna í opinberri stefnu um námsmat, par sem hvatt er annars vegar til einstaklingsmiðaðs náms og mats samkvæmt pví en hins vegar er öllum ætlað аð gangast undir samræmt mat og eru par með settir undir 
sömu mælistikuna. Slíkar pversagnir og álitamál sem peim fylgja séu pví í raun óhjákvæmilegir fylgifiskar umræðu um námsmat (Dysthe, 2008; Marsh og Willis, 2003; Meyvant Pórólfsson, Ingvar Sigurgeirsson og Jóhanna Karlsdóttir, 2009). Rúnar Sigpórsson (2008) bendir aftur á móti á að flestir námsmatsfræðingar séu sammála um að engin ein námsmatsaðferð sé réttari en önnur. Рað sé skynsamlegt að velja námsmat sem tekur mið af bæði lokamati og leiðsagnarmati eins og hæfir námsmarkmiðum.

Námsmat getur annars vegar verið formlegt mat til að safna upplýsingum um námsárangur og hins vegar ferli til að safna upplýsingum um námsárangur og námsframvindu sem eru notaðar til að leiðbeina nemendum og greina stöðu peirra (Erna Ingibjörg Pálsdóttir, 2011; Stiggins og Chappuis, 2006). Samskipti kennara og nemenda í skólastofunni eru drifkraftur náms. Kennarinn parf að örva nemendur og hvetja pá svo að peir beri aukna ábyrgð á eigin námi og skapi með sér löngun til ævilangs náms (Black og Wiliam, 1998a). Rannsóknir Black og Wiliam (1998a, 1998b) hafa sýnt fram á gildi leiðsagnarmats. Kom fram í niðurstöðum peirra að líta bæri á námsmat sem tækifæri til náms og pyrftu nemendur að vera virkir í eigin mati og færir um að sjá fyrir sér eigið nám í ljósi skilnings á pví hvað pað er að læra. Enn fremur sýndu niðurstöður peirra að aukin áhersla á leiðsagnarmat væri gagnleg öllum nemendum, sérstaklega par sem hallar á námsárangur.

Umræðan um námsmat snýst iðulega um tvo flokka mats, p.e. lokamat (e. summative assessment) annars vegar og leiðsagnarmat (e. formative assessment) hins vegar (Chappuis og Chappuis, 2002). Mikilvægt er að gera greinarmun á pví hvað pessar aðferðir fela í sér, en lokamat vísar til frammistöðumats og er pá talað um mat á námi (e. assessment of learning). Leiðsagnarmati er ætlað að styrkja sjálfsmynd nemenda og stuðla að sjálfstæðari og ábyrgari nemendum sem vita hvar peir eru staddir, hvert peir stefna og hvernig á að loka gjánni par á milli (Boaler, 2016; Erna Ingibjörg Pálsdóttir, 2011; Stiggins og Chappuis, 2006; Stiggins, Arter, Chappuis og Chappius, 2004). Námsmat á að virka sem góð endurgjöf fyrir nemendur sem eflir pá í námi og ýtir undir sjálfstraust peirra, ásamt pví að nýtast sem vottun um námsárangur (Ingvar Sigurgeirsson, 1999). Í Aðalnámskrá grunnskóla er lögð áhersla á notkun leiðsagnarmats a öllum námssviðum (Mennta- og menningarmálaráðuneytið, 2013).

Leiðsagnarmat er talið tvípætt, annars vegar mat í págu náms (e. assessment for learning) og hins vegar mat samtvinnað námi og kennslu (e. assessment as learning). Tilgangur mats í págu náms er að greina stöðu nemenda, nýta pær upplýsingar til að hafa áhrif á námsferli og efla námsárangur peirra (Chappuis og Chappuis, 2002; Earl, 2013; Stiggins o.fl., 2004). Mat í págu náms gerist í skólastofunni pegar nám á sér stað. Nemendur eru pátttakendur í eigin námi, pað eykur sjálfstraust og áhuga á námi og lögð er áhersla á próun og árangur (Chappuis og Chappuis, 2002; Stiggins o.fl., 2004; Stiggins og Chappuis, 2006). Megintilgangur matsins er að greina námsparfir nemenda, skipuleggja áframhaldandi nám og taka ákvörðun um pað, veita nemendum endurgjöf sem peir geta notað til að bæta námsferlið og hjálpa nemendum að finna að peir geti haft áhrif á eigin árangur í námi (Stiggins o.fl., 2004).

Mat, samtvinnað námi og kennslu (e. assessment as learning) er í grunninn mat í págu náms en meiri áhersla er á að nemandinn sé sá sem leggur til matsins og einnig námsferli hans. Markmiðið er að nemandinn læri að læra, p.e. að hann öðlist námsvitund (e. metacognition). Gert er ráð fyrir að nemendur ígrundi eigið nám, en pað er færni sem tekur langan tíma að próa og pjálfa. Detta gerist pegar nemendur geta fylgst með eigin skilningi, spáð fyrir um námsárangur, séð hvað peir purfa að læra, skipulagt og endurskoðað eigin hugmyndir og dregið ályktanir af peim til að dýpka skilning sinn (Earl, 2013). Lykilspurningar í pessu ferli eru: Hvert stefni ég? Hvar er ég stödd/ staddur núna? Hvernig held ég áfram? (Stiggins o.fl., 2004). Kennarar eiga að kenna nemendum sjálfsmat og ígrundun til að efla námsvitund sem stuðlar að aukinni ábyrgð og sjálfstæði nemenda í námi (Earl, 2013; Earl og Katz, 2012).

Boaler (2016) bendir á að rannsóknir sýni að pað að ná árangri liggi einkum í viðhorfi nemenda til sjálfra sín og skilaboðum sem peir fá frá kennurum og öðrum fagaðilum um nám sitt. Bestu 
tækifærin til að læra koma pegar nemendur trúa á sjálfa sig. Dweck (2016) skilgreinir trú á eigin hæfni út frá tvenns konar viðhorfum, annars vegar festusjálfi (e. fixed mindset) og hins vegar vaxtarsjálfi (e. growth mindset). Hið fyrra vísar til pess að einstaklingar hafi ekki trú á að peir búi yfir nægilegri greind og telji að sig skorti hæfileika til að hafa áhrif á og breyta stöðu sinni. Hið síðara felur í sér að einstaklingar trúi að peir geti eflt hæfileika sína með pví að takast á við fjölbreytt viðfangsefni og nota til pess innsæi og prautseigju, auk aðstoðar annarra. Dweck (2010) telur að pessi tvenns konar viðhorf hafi mikil áhrif á hegðun nemenda og vinnusemi. Nemendur taka mikilvægustu ákvarðanirnar sjálfir í námsferlinu (Chappuis og Chappuis, 2002) og er pað hlutverk kennara að ýta undir viðhorf par sem einstaklingurinn sér sig færan um að hafa áhrif á eigin árangur.

\section{Аðferð}

Hér var um eigindlega rannsókn að ræða. Megintilgangur hennar var að leita svara við pví hvernig námsmati umsjónarkennarar beita í fjölbreyttum nemendahópi. Auk pess skyldi varpað ljósi á viðhorf peirra, skilning á hugmyndinni um skóla án ađgreiningar og ákvæðum í lögum og aðalnámskrám par um.

Við pessa rannsókn var stuðst við rannsóknarsnið fyrirbærafræðinnar (e. phenomenology) en markmið hennar er að skoða ólík sjónarmið og rannsaka upplifun og reynslu viðmælenda (Lichtman, 2013). Rannsókn pessari var ekki ætlað að gefa tölfræðilegar upplýsingar um stöðu námsmats innan skólanna heldur gefa skýrari mynd af pví hvernig námsmati umsjónarkennararnir beita par sem áhersla er lögð á nemandann sem virkan pátttakanda í eigin námi óhád líkamlegu eða andlegu atgervi.

\section{Dátttakendur}

Haft var samband við skólastjóra í Kópavogi, óskað eftir samvinnu og peir beðnir um ábendingar um umsjónarkennara á yngsta stigi sem hefðu reynslu af að vinna í fjölbreyttum nemendahópi. Pátttakendur voru valdir með tilgangsúrtaki (e. purposive sampling) og leitað til einstaklinga sem taldir voru búa yfir víðtækri pekkingu á málefninu (Sigríður Halldórsdóttir, 2016).

Allir pátttakendur fengu kynningarbréf með yfirlýsingu um upplýst sampykki fyrir rannsókninni. Deim voru gefin tækifæri til að spyrja nánar út í rannsóknina, tilgang hennar og frekari úrvinnslu. Lögð var áhersla á að gefa pátttakendum greinargóðar upplýsingar um rannsóknina, tilgang hennar, hvað fælist í pátttöku peirra og réttindum, svo og upplýsingar um skyldur rannsakanda gagnvart peim. Allir pátttakendur skrifuðu undir sampykkisyfirlýsinguna. Hér á eftir er stutt lýsing á pátttakendum en peir fengu allir dulnefni ásamt skólum peirra.

Fjóla er umsjónarkennari í 3. bekk í Reynisskóla með 12 ára starfsreynslu, par af tvö ár í núverandi skóla, sem grunn- og leikskólakennari. Anna er umsjónarkennari í 4. bekk í Birkiskóla og með 15 ára starfsreynslu. Harpa og Elva eru umsjónarkennarar í 3. bekk í Furuskóla. Harpa er með 10 ára starfsreynslu og Elva 11 ára starfsreynslu. Dær vinna saman í teymiskennslu. María er umsjónarkennari í 1. bekk í Asparskóla með 8 ára starfsreynslu sem grunnskólakennari, par af eitt ár í núverandi skóla.

\section{Gagnaöflun og greining}

Gagnaöflun beindist að tveimur páttum. Annars vegar var rýnt í opinber gögn sveitarfélagsins og kannað hver stefna pess í menntamálum væri hvað varðaði skóla án aðgreiningar og skólanámskrár allra grunnskóla bæjarins skoðaðar. Hins vegar var gagna aflað með einstaklingsviðtölum við fimm umsjónarkennara í fjórum skólum. Fyrirliggjandi gögn sveitarfélagsins og skólanámskrár pátttakenda voru orðræðugreind og fyrst og fremst höfð til hliðsjónar við undirbúning viðtala. 
Í peim hluta gagnaöflunar sem sneri að opinberum gögnum, bæði sveitarfélagsins og grunnskólanna, var leitað sérstaklega eftir orðum eða hugtökum tengdum skóla án aðgreiningar og námsmati. Í skjölum sveitarfélagsins var auk pess skoðuð sérstök stefna pess um jafnrétti og mannréttindi og hvernig hún birtist í skólanámskrám grunnskólanna. Par var sjónum beint að pví hvernig skóli án aðgreiningar væri skilgreindur, hvað segði almennt um námsmatsaðferðir peirra, en einnig hvernig námsmat birtist með tilliti til stefnunnar.

Seinni hluti rannsóknarinnar, p.e. viðtölin, byggðust að vissu leyti á peim upplýsingum sem fengist höfðu við greiningu fyrirliggjandi gagna. Fyrst og fremst var leitað til peirra skóla sem tóku skýrt fram í sínum skólanámskrám að peir störfuðu samkvæmt stefnunni um „skóla án aðgreiningar“ eða notuðu hugtök nátengd stefnunni í skólanámskrám eða áætlunum.

Tekin voru fjögur viðtöl við fimm kennara, en eitt var tekið við tvo umsjónarkennara í einu vegna pess að peir unnu saman í teymi og töldu pað gefa betri mynd af umfjöllunarefninu. Viðtölin fóru fram á starfsvettvangi pátttakenda og tímalengd peirra var 25-60 mínútur. Pau voru hálfopin (e. semi-structured interviews) með viðtalsramma. Að loknum viðtölum voru pau afrituð orðrétt og frumgreind jafnóðum, auk pess sem frekari hugrenningar um viðtölin voru skráðar niður. Viðtölin voru borin undir pátttakendur og peim gefinn kostur á að breyta eða bæta við pað sem hafði verið skrifað svo gætt væri að pví að farið væri rétt með frásagnir peirra. Að lokum voru viðtölin greind út frá lykilhugtökum og flokkuð; einnig voru pemu greind út frá pemagreiningu Braun og Clarke (2006).

\section{Niðurstöður}

Í pessum kafla er gerð grein fyrir niðurstöðum rannsóknarinnar. Fyrst er fjallað um niðurstöður á greiningu opinberra gagna. Pá er peim tveimur pemum lýst sem komu í ljós pegar gögnin úr viðtölunum voru greind. Fyrra pemað beinir sjónum að skóla án aðgreiningar og seinna pemað lýsir pví hvernig pátttakendur sjá fyrir sér námsmat í skóla án ađgreiningar.

\section{Opinber gögn og skólanámskrár}

Opinber gögn sveitarfélagsins og námskrár skólanna voru einkum höfð til hliðsjónar við undirbúning viðtalanna. Î peim skilningi var ekki um eiginlega orðræðugreiningu að ræða heldur áherslur í stefnu skólanna um hugtök tengd skóla án aðgreiningar og námsmati.

Í opinberum gögnum sveitarfélagsins er lögð sérstök áhersla á jafnréttis- og mannréttindamál og tekið er sérstaklega fram að grunnskólar eigi að taka mið af peim. Í pessu sambandi er nefnd jöfn staða kynja, að námsefni endurspegli margbreytileika samfélagsins og að taka skuli mið af pörfum fatlaðra og fjölmenningu. Dessi hugtök geta pví fallið undir skilgreiningu skóla án aðgreiningar. Aðeins einn pátttökuskólinn tekur skýrt fram stefnu um skóla án aðgreiningar, annar talar um skóla fyrir alla, priðji skólinn leggur áherslu á einstaklingsmiðað nám og sá fjórði talar um nám við hæfi allra. Stefna um námsmat birtist í premur skólanna og er par tekið fram að um leiðsagnarmat sé að ræða.

\section{Skóli án aðgreiningar}

Pátttakendur áttu allir auðvelt með að koma orðum að skilgreiningu á hugtakinu skóli án aðgreiningar. Ummæli peirra voru nokkuð samhljóða í pá veru að skóli án aðgreiningar væri skóli par sem börn með sérparfir stunduðu nám, í flestum tilfellum með öðrum nemendum í almennri skólastofu og ekki aðgreind frá hópnum. Pá talaði Anna um að í slíkum skóla pyrfti að vera hægt að sinna öllum börnum, óháð pví hvort pau væru fötluð eða ekki og huga pyrfti að einstaklingsmiðun. Einn viðmælandi sagði að skóli án aðgreiningar væri „,kkóli par sem allir fá tækifæri til pess að njóta sín eins og peir eru“. Talaði María sérstaklega um mikilvægi pess að 
hugsað væri um einstaklinginn og að skólinn pyrfti að hafa úrræði til pess að koma til móts við parfir hans. Voru pátttakendur sammála pví að meta pyrfti einstaklinginn út frá hans forsendum, eins og fram kemur í orðum Maríu:

Skóli án aðgreiningar er bara nám við hæfi fyrir alla. Stundum svolítið erfitt að koma pví að en við reynum okkar besta. Maður parf bara að horfa [á] petta út frá einstaklingnum, bara hjá hverjum fyrir sig ... Einstaklingurinn skiptir svo miklu máli. (María í Asparskóla)

Visst prástef mátti greina hjá öllum viðmælendum um að aukið fjármagn pyrfti til skólanna svo vel tækist til. Benti einn pátttakandinn á að hugmyndin um skóla án aðgreiningar væri ásteytingarsteinn hjá mörgum kennurum og beindist ekki að nemendunum sjálfum, heldur ,að pað fylgdi ekki sem pyrfti til að gera petta vel“. Umræðan um menntastefnuna væri pví almennt neikvæð, en ekki vegna pess að kennarar væru ósampykkir stefnunni. Skortur á fjármagni og stuðningi fagaðila í bekk eða námshópi gerði kennurum hins vegar erfitt fyrir að fylgja stefnunni eins og eftirfarandi ummæli bera með sér:

Ég held pað séu flestir sammála pví að hérna, að petta er alveg ógeðslega erfitt pegar pú færð ekki nógu mikinn stuðning í kringum pig. Að vera með kannski stóran bekk og fullt af nemendum sem að purfa svo mikla einstaklingspjónustu. (Harpa í Furuskóla)

Mér finnst líka að ef petta skóli án aðgreiningar eigi að virka pá verður, eða mér finnst аð pað ætti að vera stuðningsfulltrúi í hverjum einasta bekk á yngra stigi. Af pví að pað eru alveg pað mörg börn í hverjum hópi sem purfa aðstoð. Meiri heldur en kennarinn getur kannski veitt. (Elva í Furuskóla)

Degar pátttakendur voru spurðir hvernig umræðan um skóla án aðgreiningar væri innan skólans, eða hvort hún ætti sér yfirleitt stað, komu fram talsvert neikvæð viðbrögð. Bentu Harpa og Elva á að lítil umræða ætti sér stað um stefnuna innan skólans sem pær störfuðu í og pá aðallega um pað að stefnunni fylgdi ekki pað fjármagn sem pyrfti og að pað reyndist kennurum erfitt. Í einum skólanna voru hins vegar miklar umræður og sagði Fjóla að kennarar hefðu sterkar skoðanir á stefnunni en umræðurnar snerust yfirleitt um pað að „,fólki finnst virkilega vanta fólk til pess að anna pessu“. María talaði einnig um eftirfarandi:

Sko, hún [umræðan] kemur upp annað slagið og pá kemur hún alltaf upp á sama, pú veist, á sama róli. Pá er hún bara neikvæð. Рað sé sem sagt að pessi stefna gangi ekki upp. Рað er alltaf pannig. (María í Asparskóla)

Í samtölum höfðu pátttakendur greint frá pví að skóli án aðgreiningar fæli meðal annars í sér pátttöku nemenda með sérparfir inni í almennu bekkjarstarfi. Deir voru spurðir nánar út í hvað full pátttaka pýddi og hver afstaða peirra væri til hennar. Svör peirra voru að sumu leyti samhljóða og höfðu prír viðmælendur orð á pví að horfa pyrfti til hvers og eins í pví sambandi. María sagði um petta: „Баð fer svo rosalega eftir einstaklingnum ...“ og vísaði til félagslegs styrkleika nemenda. Fjóla var sammála pessu:

раð sé frekar hver einstaklingurinn er sem að parf að skoða. Hvort hann poli pað eða vill pað, eða getur pað, verið allan daginn inni í bekknum. Ég held ég myndi meta pað pínulítið einstaklinginn. (Fjóla í Reynisskóla)

Pátttakendur voru almennt jákvæðir gagnvart pví að nemendur með sérparfir væru hluti af bekknum og töldu að peir ættu með réttum stuðningi að geta stundað nám innan bekkjarins. Рað færi pó vissulega alltaf eftir pörfum hvers einstaklings hvort og hvenær hann væri inni í bekk eða námsveri. Pó gátu tveir viðmælendur pess að út frá sjónarmiðum jafnréttis og mannréttinda fyndist peim peir brjóta á réttindum hinna barnanna sem pyrftu að líða fyrir truflandi og erfiða hegðun annarra nemenda og fyndist peir verða útundan og gleymast. Deim tækist pví ekki nægilega vel að stuðla að fullri pátttöku allra nemenda. Taldi Anna að erfiðleikarnir í 
kennslu birtist einkum pegar nemendur sem væru „,algerlega óheflaðir“ eða peir sem væru með „mótstöðuprjóskuröskun“ væru inni í bekk. Elva tók undir og sagði jafnframt:

Mér finnst við líka stundum upplifa pað að, sko, maður er búinn að vinna og vinna allan daginn með börn og svo hugsar maður bara, pessi gleymdist, pessi gleymdist. Pannig að раð ... eru svo margir aðrir sem taka athygli frá hinum. (Elva í Furuskóla)

Allir skólarnir höfðu markað sér stefnu um hvernig skyldi koma til móts við parfir nemenda og var par talað um einstaklingsmiðun eða einstaklingsnámskrá væri pess pörf. Pátttakendur voru spurðir nánar hvernig peir kæmu til móts við parfir nemenda sem pyrftu á sérstökum úrræðum að halda og hvernig peir ynnu með ólíkan nemendahóp. Viðmælendur voru sammála pví að peirra skólar væru mjög vel settir miðað við marga aðra og væru ýmist með góð námsver eða sérkennslurými. Töluðu prír viðmælendur um að sérkennarar sæju pó almennt um gerð einstaklingsnámskrár fyrir pá nemendur sem pyrftu sérstakan stuðning í námi og proska. Einn viðmælandi tók pó fram að ekki hefði purft að búa til einstaklingsnámskrá hjá sínum nemendahópi. Pá gat María pess að ekki væri unnið með einstaklingsnámskrár í 1. bekk heldur færi fram endurmat á færni nemandans fyrir 2. bekk og ákvörðun væri tekin pá.

Einn pátttakandi hafði orð á pví að nemendur væru á mörgum stigum varðandi getu til náms, áhersla væri lögð á að allir fengju tækifæri og reynt væri að finna leiðir fyrir alla. Voru viðmælendur sammála pví að fjölbreytt nám og kennsla skipti gríðarlega miklu máli og að beitt væri fjölbreyttum kennsluaðferðum til að reyna að ná til allra nemenda. Pá töluðu allir viðmælendur um að aukinn stuðningur nemenda í námi væri fyrst og fremst stuðningur við lestur og væru peir frekar í sérverkefnum en sérkennslu. Einn pátttakandi talaði um að stöðvavinna 1 anda Byrjendalæsis hefði gefið aukið svigrúm til að aðstoða nemendur sem pyrftu aukinn stuðning í námi.

\section{Námsmat}

Viðmælendur voru spurðir hvað peir teldu námsmat fela í sér og voru peir einróma um að námsmat fæli í sér að meta hvar nemendur væru staddir í námi og hvað pyrfti að vinna með til að peir næðu vissum námsmarkmiðum. Talaði einn viðmælandi um að námsmati væri ekki aðeins beitt til pess að mæla sem mest og flest. Í pví samhengi bentu prír pátttakendur á hvað mætti gera betur og hvernig kennarar gætu nálgast nemendur betur eins og eftirfarandi ummæli Fjólu bera með sér:

Mér finnst pað líka til pess að maður geti séð hvort pað purfi að gera eitthvað betur. Mér finnst pað líka gott fyrir nemandann til að hann sjái hver staðan sín er, hvort hann purfi að vinna betur í einhverjum málum. Já, mér finnst pað svona eiginlega að taka stöðuna. (Fjóla í Reynisskóla)

Aðspurðir um stefnu skólans í námsmati komu fram ólík svör. Drír pátttakendur sögðu að mikið samræmi væri innan skólans um námsmatið, skýr markmið í hverjum árgangi og skýrt hvernig námið skyldi metið. Í einum skólanum var stefnan sú að á yngsta stigi væri aðeins notuð umsögn og að hæfniviðmiðin yrðu öll komin inn á Mentor (p.e. skólaárið 2017-2018) og hægt að „haka við“ hvert og eitt. Talaði Anna um að auk pessa væri komin ákveðin hefð og par af leiðandi væri pað ekki hver og einn kennari sem ákvæði námsmatið hverju sinni. Fjóla gat pess pó að skólanámskráin innihéldi námsmarkmið en pað væri í höndum hvers kennara að útfæra námsmatið innan bekkjarins. Pá kom í ljós að hún var nýr kennari í viðkomandi skóla og hafði ekki fengið leiðsögn um námsmatið.

Ég hefði alveg viljað [аð] farið [hefði verið] yfir pað. Svona vinnum við, í staðinn fyrir að maður sé svona að leita og prófa eitthvað sem maður hefur verið að gera annars staðar en svo passar pað ekkert inn í nýjan skóla og eitthvað. (Fjóla í Reynisskóla) 
Megintilgangur rannsóknarinnar var að kanna hvernig námsmati umsjónarkennarar beita í fjölbreyttum nemendahópi. Pátttakendur voru beðnir að lýsa helstu námsmatsaðferðum sínum og hvernig peir ynnu með námsmat. Niðurstöður voru nokkuð líkar en pað fór verulega eftir pví í hvaða árgangi peir kenndu. „Í pessum yngstu bekkjum pá er maður að fylgjast mikið með pví hvar pau eru í hvert skipti og líka bara ... hvar pau stoppa." Fjórir viðmælendur töluðu um að petta fæli í sér miklar óformlegar skráningar, en pær væru mikilvægur hluti af námsmatinu. Námsmatsaðferðir viðmælenda voru fjölbreyttar og mikið lagt upp úr að nota sjálfsmat og jafningjamat. Símat (e. ongoing assessment) var helsta matsaðferð peirra, en pað er mat samhliða námi og sífellt í gangi, pess vegna óformlegt og oft án vitundar nemenda. Pá nefndu pátttakendur að vottun um námsárangur birtist einungis 1 umsögn eða bókstöfum. Auk pess notuðu allir pátttakendur umsjónarkerfið Mentor. Fram kom að námsmatið væri að breytast vegna nýja námsmatskerfisins, p.e. með matskvörðunum A, B, C og D. Talaði einn viðmælandi um að skilaboð til nemenda væru á pá leið að nánast ógerningur væri að fá $\mathrm{A}$, vegna pess að pað væri túlkað sem framúrskarandi, en pá pyrfti nemandi að ljúka verkefninu auk pess að gera eitthvað umfram pað sem beðið væri um og væri pað „,rosalegt niðurbrot“.

Allir pátttakendur nefndu einnig að skólarnir væru ýmist með leiðsagnarmat eða frammistöðumat samkvæmt Mentor eða hvort tveggja, sem væri reglubundinn páttur í öllum árgöngum. Dar gætti pess misskilnings að um sama námsmat væri að ræða, p.e. að leiðsagnarmat væri pað sama og frammistöðumat. Tveir pátttakendur höfðu nefnt leiðsagnarmat að fyrra bragði en allir voru spurðir hvort peir notuðu leiðsagnarmat í kennslu og hver pátttaka nemenda væri í pví. Í öllum tilfellum bárust samræður fljótlega að umsjónarkerfinu Mentor í pví sambandi og sögðu kennarar að peir hefðu notað leiðsagnarmat á Mentor. Aðeins einn kennari talaði um að hafa notað leiðsagnarmat í kennslu, en pað hefði verið með nemendum á miðstigi:

Ég hef sko gert svoleiðis og látið pau setja sér markmið og ... hef verið með áætlanir ... Pá gera pau sjálf svona einstaklingsáætlun fyrir sig [og] pá eiga pau einmitt að gera markmið við upphaf pú veist, fyrir sig, og pá koma pau í svona viðtöl til mín. (Anna í Birkiskóla)

Pátttakendur voru allir sammála pví að börn á yngsta stigi gætu sett sér markmið og peir töldu pað jákvætt að nemendur tækju pátt í námsmatinu. Đá nefndi einn kennarinn að sinn skóli notaði námskvarða (e. rubric) sem nemendur fengju að sjá fyrirfram og vissu par af leiðandi hver markmiðin væru. Einn viðmælandinn sagði að nemendur settu sér alls konar markmið, einkum í lestri og bættum samskiptum, og pau kæmu frá nemendum sjálfum.

Pátttakendur voru sammála um að pað gengi nokkuð vel að meta alla nemendur og væru peir í vafa gætu peir leitað til samkennara sinna eða sérkennara. Hafði einn viðmælandi orð á pví аð pað væri mikilvægast að horfa á pað jákvæða hjá hverjum og einum og nota uppbyggjandi námsmat. Námsmatið í tengslum við skóla án aðgreiningar væri pó pess eðlis að pað væri alltaf áskorun að meta og koma til móts við alla nemendur.

Dað er náttúrulega út af pví að maður er að reyna að hugsa út frá pessu, skóli án aðgreiningar. Dau eru ekki öll á sama stað og pau eru ekki, pau eru mislangt komin ... Dannig að auðvitað verður maður að leggjast yfir hvern einasta nemanda bara. Detta er alveg krefjandi og petta er alveg, tekur mikinn tíma. (Harpa í Furuskóla)

Dátttakendur voru spurðir hvort peir upplifðu valpröng (e. dilemma) pegar kæmi að námsmati í fjölbreyttum nemendahópi. Fjórir viðmælendur nefndu samræmdu prófin og töldu pau vera í algerri andstöðu við menntastefnuna. Auk pess gætu breytingar á fyrirkomulagi prófanna, að pau væru að hausti en ekki vori, stýrt skólastarfinu.

Mér finnst alltaf slæmt pegar pað parf að láta miða allt skólastarfið við pað hvað kemur á samræmdu prófi. Dað er náttúrulega bara mjög slæmt, sko, og kemur í veg fyrir ... skapandi starf. (María í Asparskóla) 
Đá töluðu sömu fjórir viðmælendur um að peir sæju ekki tilganginn með prófunum, par sem erfitt væri að átta sig á hvar námslegir erfiðleikar nemenda lægju hjá hverjum og einum. Prófin væru auk pess löng, reyndu mikið á úthald og væru mörgum afskaplega erfið, líka foreldrum.

Samræmd próf henta ekkert skóla án aðgreiningar. Ég meina, par er sama prófið fyrir alla.

Og hérna erum við að búa til mismunandi próf út af pví að pað eru mismunandi börn.

(Harpa í Furuskóla)

\section{Umræður}

Meginniðurstöður pessarar rannsóknar koma heim og saman við fyrri rannsóknir á skóla án aðgreiningar, sem fjallað er um í fræðilegum hluta, hvað varðar viðhorf og skilning á stefnunni annars vegar og námsmat í skóla án aðgreiningar hins vegar. Dregnar eru fram ályktanir um pað hvernig megi nýta niðurstöðurnar til að skoða nánar hvaða möguleika mat í págu náms gefur kennurum til að starfa í anda menntastefnunnar.

Viðhorf og skilningur

Dátttakendur pessarar rannsóknar höfðu nokkuð sambærilegan skilning á hvað stefnan felur í sér, p.e. að í skóla án aðgreiningar fái allir nám við hæfi og tækifæri til að njóta sín á eigin forsendum auk pess að skólar taki við öllum nemendum, óháð fötlun og uppruna. Hins vegar má greina af svörum pátttakenda að auka purfi skilning kennara á grundvallarhugmyndum á borð við fulla pátttöku, félagslega og námslega, allra nemenda í skólastarfinu. Birtist petta einkum í umræðu priggja pátttakenda um hvar nemendur með sérparfir eru staðsettir innan skólanna. Allir pátttakendur voru hins vegar meðvitaðir um að nemendur með sérparfir ættu rétt á að upplifa sjálfa sig fullgilda í almennum bekk, en starfshættir einkenndust af pví að peir væru utan skólastofunnar og í sérkennslu eða námsveri. Svipaðar niðurstöður komu fram í rannsókn Hermínu Gunnpórsdóttur og Dóru S. Bjarnason (2014), að íslenskir kennarar hefðu ekki fullan skilning á hugtökum tengdum stefnunni. Nauðsynlegt er að sameiginlegur skilningur sé til staðar á inntaki stefnunnar hjá öllum peim sem koma að menntamálum, ekki aðeins kennurum (European agency for special needs and inclusive education, 2017).

Eðli málsins samkvæmt ýtir pað undir aðgreiningu og einangrun minnihlutahópa ef ákveðnir einstaklingar eða hópar eru teknir út úr skólastofunni. Pað getur viðhaldið pví viðhorfi að fjarlægja purfi einstaklinga sem trufla nám peirra sem falla undir ákveðna hugmynd um hvernig nemendur eiga að vera (Ainscow, Dyson og Weiner, 2013; Jóhanna Karlsdóttir og Hafdís Guðjónsdóttir, 2010; Moen, 2008). Tveir af pátttakendum töluðu um petta atriði og kom fram samviskubit hjá öđrum peirra gagnvart peim nemendum sem hefðu sig lítið í frammi. Nám í anda skóla án aðgreiningar miðar að pví að útrýma útilokun jaðarhópa og byggir á umburðarlyndi, jafnrétti og lýðræðislegu samstarfi pannig að stuðlað sé að virkri pátttöku og ábyrgð allra nemenda (Menntaog menningarmálaráduneytið, 2013).

Samkvæmt svörum pátttakenda pessarar rannsóknar var lítil umræða innan priggja skóla um stefnuna en í einum skóla var hún mikil. Umræðurnar einkenndust af neikvæðu viðhorfi, ekki gagnvart nemendunum sjálfum heldur innleiðingu stefnunnar og peim úrræðum sem almennum kennurum hefur staðið til boða. Gagnrýndu pátttakendur einna helst skort á fjármagni til skólanna, en peir töldu að auka pyrfti pað til muna svo skólastarfið gengi betur. Parna mátti greina visst ráðaleysi kennara gagnvart pví að stuðla að pátttöku allra nemenda í bekkjarstarfi, og peir töldu að ætti slíkt að ganga eftir pyrfti aukinn stuðning í formi sérhæfðara starfsfólks, s.s. iðjupjálfa, proskapjálfa og fleiri sérkennara sem hefðu haldbæra pekkingu á ólíkum sviðum sérparfa. Rétt eins og niðurstöður Hermínu Gunnpórsdóttur og Dóru S. Bjarnasonar (2014) benda til, rekja kennarar vandann til ytri aðstæðna og telja skort vera á faglegum stuðningi og sérkennslu nemenda með sérparfir í bekk eða námshópi. 
Að framansögðu má sjá að pátttakendur finna fyrir skorti á umræðum um menntastefnuna og prástef peirra um aukinn stuðning gefur til kynna ákveðið úrræðaleysi peirra gagnvart fjölbreyttum nemendahópum, einkum nemendum með hegðunarvanda. Skapar petta gremju, sektarkennd og togstreitu meðal kennaranna gagnvart nemendum með sérparfir, en einnig nemendum sem purfa ekki á sérúrræðum að halda. Kemur petta heim og saman við úttekt Evrópumiðstöðvarinnar (European agency for special needs and inclusive education, 2017) á framkvæmd stefnu um skóla án aðgreiningar hérlendis. Par er bent á að auka purfi umræður meðal peirra sem vinna að menntamálum og skapa vettvang fyrir pær. Auk pess sé brýn nauðsyn á endurskoðun núverandi fjármögnunarferlis og hvernig pví er beitt. Nú á dögum er skólum úthlutað fjármagni út frá formlegum greiningum nemenda. Dessi aðferð sætir mikilli gagnrýni par sem áhersla á greiningar sé of mikil og pær stjórni fjárúthlutunum til skólanna. Í skýrslunni kemur eftirfarandi fram: „Í stað pess að auka fjárveitingar til menntakerfisins er áríðandi að nýta pá fjármuni sem nú eru til ráđstöfunar á annan, skilvirkari og hagkvæmari hátt" (European agency for special needs and inclusive education, 2017, bls. 94).

Niðurstöður pessarar rannsóknar sýna að fjórir af fimm pátttakendum hafa góðan skilning á hugtökum um jafnrétti og mannréttindi. Deir telja pað frumskilyrði að öllum börnum séu gefin tækifæri til menntunar og nám við hæfi og hlúð sé að vellíðan nemenda. Drír viðmælendur upplifa hins vegar að ekki sé stuðlað nægilega vel að jafnrétti allra nemenda. Баð kemur fram sem samviskubit yfir pví að geta ekki gefið nægilega af sér pannig að allir nemendur njóti pess sama. Tala peir einkum um að án aðstoðar inni í bekk takist peim ekki að veita öllum nemendum athygli og stuðning. Dar með sé brotið á rétti sumra á kostnað annarra. Dessar niðurstöður eru í samræmi við fyrri rannsóknir (Ainscow, 2008; Banks, 2007) sem sýna að slík viðhorf valda innri togstreitu meðal kennara sem dregur úr ánægju af starfinu. Niðurstöður sýna að núverandi fjárveitingar koma í veg fyrir að öllum nemendum sé sinnt af kostgæfni og í takt við parfir peirra (European agency for special needs and inclusive education, 2017).

Athygli vakti í rannsókninni hversu sterk umræða var um einstaklinginn, parfir hans og úrræði í almennu skólastarfi. Bendir petta til góðs skilnings á margbreytilegum pörfum innan fjölbreytts nemendahóps. Reynt er að koma til móts við parfir allra og í pví samhengi talað um einstaklingsmiðun eða einstaklingsnámskrá. Almennt var vísað til pess að nemendur með greiningar fengju einstaklingsnámskrá en nám peirra sem pyrftu á auknum námsstuðningi að halda væri einstaklingsmiðað með раð аð leiðarljósi að sníða námið að pörfum hvers og eins. Af svörum pátttakenda mátti greina umhyggju peirra fyrir öllum nemendum og skilning á mikilvægi pess að allir fengju nám við hæfi. Kemur pað fram sem jákvæð próun hugmynda um að pað sé skólans að laga sig að pörfum hvers nemanda en ekki að nemandinn sé aðlagaður skólanum (Tetler, 2005).

Niðurstöður rannsóknarinnar sýndu að innan peirra priggja skóla sem notuðu einstaklingsnámskrá fælu umsjónarkennarar sérkennurum alfarið pá ábyrgð að útbúa hana. Samkvæmt Aðalnámskrá grunnskóla eiga umsjónarkennarar að bera ábyrgð á námi nemenda sinna en með aðstoð annarra fagaðila (Mennta- og menningarmálaráðuneytið, 2013). Баð kemur einnig fram í viðtali við Trausta Porsteinsson um skóla án aðgreiningar að sú stefna feli í sér lýðræðisleg gildi, samheldni og sameiginlega ábyrgð. Jafnframt miðar stefnan að sampættu menntakerfi og samstarfi umsjónarkennara og fagaðila til að stuðla að gæðamenntun hvers nemanda (Guðmundur Heiðar Frímannsson, Rósa Eggertsdóttir og Rúnar Sigpórsson, 2013).

\section{Námsmat og hlutverk pess}

Tveir pátttakendur höfðu orð á að námsmat hefði tekið breytingum undanfarið og að nú væri minni áhersla lögð á próf. Fjórir viðmælendur töldu einnig að á yngsta stigi væri símat mest notað par sem fylgst væri með stöðu hvers og eins reglulega yfir skólaárið og gripið inn í pegar pörf pætti. Niðurstöður rannsóknarinnar benda til pess að pátttakendur hafi góða yfirsýn yfir 
nemendahóp sinn hvað varðar proska og getu, og viti pví vel hvenær peir purfa að grípa inn í námsferil peirra.

Ljóst er að pegar Aðalnámskrá grunnskóla er skoðuð er fátt par sem segir hvernig námsmati í skólum án aðgreiningar skuli háttað. Er par aðeins vísað til nemenda með sérparfir og að peir eigi rétt á að komið sé til móts við parfir peirra með breyttum áherslum í námsmati, einkum með lengri próftíma, sérhönnuðum prófum og notkun hjálpargagna (Mennta- og menningarmálaráðuneytið, 2013).

Degar ráðaleysi kennara í sambandi við námsmat og stefnumörkun er haft í huga er eðlilegt að togstreita skapist par sem annars vegar er hvatt til einstaklingsmiðaðs náms og námsmats samkvæmt pví en hins vegar er öllum nemendum ætlað að preyta samræmd próf. Slíkt getur valdið valpröng hjá kennurum og pversögnum í starfi peirra. Ekki mátti pó greina á pátttakendum að peir fyndu mikið fyrir slíkri togstreitu í daglegu starfi, en fjórir viðmælendur höfðu aftur á móti sterkar skoðanir á samræmdum lokaprófum og tilgangi peirra. Fram kom að peim pættu samræmd lokapróf tilgangslaus og í andstöðu við stefnuna um skóla án aðgreiningar. Enn fremur töldu peir að pau hefðu stýrandi áhrif á nám og kennslu og einn pátttakandi taldi pau draga úr skapandi skólastarfi. Sterk viðbrögð pátttakenda pegar prófin bárust í tal gáfu til kynna að peir upplifðu að peir væru milli steins og sleggju, par sem peir vildu mæta pörfum hvers og eins í námsmati en svo væru allir nemendur settir undir sama hatt pegar kæmi að stórum prófum eins og samræmdu prófunum (Meyvant Dórólfsson o.fl., 2009). Dessar niðurstöður koma heim og saman við fyrri rannsóknir, en par kemur fram að kennurum pyki samræmd próf vera árás á fagmennsku peirra og pau fái pá til að upplifa að peir hafi ekki stjórn á eigin starfsháttum (Hermína Gunnpórsdóttir, 2010).

Megintilgangur rannsóknar var að kanna hvernig námsmati umsjónarkennarar beita í fjölbreyttum nemendahópi. Fram kom í pessari rannsókn að allir pátttakendur nota fjölbreytt námsmat til að meta stöðu nemenda sinna. Auk símats nota peir kannanir og próf, jafningjamat og sjálfsmat. Đá töluðu allir pátttakendur einnig um frammistöðumat og leiðsagnarmat. Að pví leyti tekst umsjónarkennurum ágætlega til að beita fjölbreyttu námsmati miðað við einstaklingsbundnar parfir. Degar kemur hins vegar að skráningu og formlegum vitnisburði um námsárangur virðist Mentor hafa áhrif á hvernig hann birtist. Nefna má leiðsagnarmat í pví sambandi eins og pað fer fram í skráningarkerfi Mentors, en pað er reglubundinn páttur í námsmati skólanna sem mat foreldris/ra og barns tvisvar á ári.

Degar svör pátttakenda eru skoðuð má sjá að misskilningur ríkir varðandi notkun leiðsagnarmats í kennslu. Leiðsagnarmat á sér stað pegar nemandi og kennari eru virkir í samræðum og nemanda gefst tækifæri til að ígrunda hvert hann stefnir, hvar hann er staddur núna og hvernig hann heldur áfram. Gagnvirk samskipti nemanda og kennara eru pví lykilatriði í pessu samhengi (Earl, 2013; Stiggins og Chappuis, 2006). Mikilvægt er að fagleg umræða um námsmat eigi sér stað í skólum með pað að leiðarljósi að ýta undir námsvitund nemenda, stuðla að námshvatningu og auka sjálfstraust nemenda og trú á sjálfum sér (Earl, 2013; Earl og Katz, 2012).

\section{Ályktanir}

Degar umfjöllun um skóla án aðgreiningar er annars vegar kemur fram að skortur er á slíkri umræðu innan skólanna. Degar hún kemur upp einkennist hún af neikvæðu hugarfari og segja má að umræðan verði til pess að móta viðhorf kennaranna og að hún hafi áhrif á upplifun peirra af skólastarfi í skóla án aðgreiningar. Draga má pá ályktun að pátttakendur hafi svipaðan skilning á inntaki stefnunnar en ljóst er að skilgreina parf betur á hvaða gildum hún er byggð hjá öllum aðilum sem koma að menntamálum svo komið sé til móts við réttindi allra barna til að stunda nám. Til pess parf virkar umræður innan skóla og utan, par sem öllum eru gefin tækifæri til að endurmóta skoðanir sínar og viðhorf. Til að skapa slíkan samræðuvettvang parf að skilgreina 
hugtakið skýrar í menntastefnu landsins og gera pað aðgengilegra fyrir kennara og aðra innan skólasamfélagsins að skilja málefnið (European agency for special needs and inclusive education, 2017).

Hjá pátttakendum kom ítrekað fram pað viðhorf að auka pyrfti fjármagn til skólanna svo stefnan gengi betur. Bentu peir á að fleira sérmenntað fagfólk pyrfti inn í skólana til að hægt væri að mæta pörfum og getu hvers og eins. Í skýrslu Evrópumiðstöðvar (European agency for special needs and inclusive education, 2017) kemur fram að miklum fjármunum er varið til skólanna hér á landi en slíkar fjárveitingar eru háðar kvöðum, p.e. að aukið fjármagn fæst gegn formlegri greiningu á sérpörfum nemenda. Æskilegt er að breyta slíku fyrirkomulagi pví pað ýtir undir aðgreiningu og neikvæð viðhorf til stefnunnar. Lagt er til í skýrslunni að pessum fjármunum sé betur varið til að styrkja innra starf skóla.

Greina mátti jákvæða próun námsmats og beitingar pess hjá pátttakendum í rannsókninni, par sem mikil áhersla var lögð á fjölbreytt námsmat en lítið bar á að beitt væri leiðsagnarmati í almennri kennslu. Notkun leiðsagnarmats sýnir með afgerandi hætti hvernig ýta má undir trú nemenda á sjálfa sig (Black og Wiliam, 1998a, 1998b; Earl, 2013). Leiðsagnarmat er tæki fyrir kennara til að efla pátttöku nemenda í eigin námi og pað kennir peim að bera ábyrgð á eigin framförum. Styrkja verður pá hugsun að mati megi beita í págu náms, en til pess parf breytt hugarfar. Námsmati er fyrst og fremst ætlað að vera nemendum leiðbeinandi og hvetjandi í námi (Mennta- og menningarmálaráðuneytið, 2013). Með leiðsagnarmati má próa viðhorf vaxtarsjálfs hjá kennurum og nemendum. Kostir pess eru ótvíræðir, t.d. í sambandi við að efla eigin getu til aðgerða (Kristján Kristjánsson, 2007).

Degar notkun pátttakenda á leiðsagnarmati er aftur á móti skoðuð nánar má sjá hvar misskilnings gætir og var peim tíðræett um Mentor í pví samhengi. Fram kom að leiðsagnarmat færi fram í gegnum Mentor, tvisvar á ári par sem foreldri og barn settu sér markmið saman. Slík notkun er 1 andstöðu við hvernig leiðsagnarmati skuli beitt, p.e. utan skólastofunnar en ekki innan hennar í gagnvirkum samræðum kennara og nemenda. Auk pessa má telja líkur á pví að Mentor hafi stýrandi áhrif pegar kemur að vitnisburði um námsárangur nemenda. Hér parf að staldra við og skoða hvers vegna Mentor hafi slík áhrif, hvaða stefnu skólastjórnendur hafa sett með notkun pess og umfram allt hvernig pví er ætlað að auka námsárangur allra nemenda.

Ljóst er að pátttakendur sinna starfi sínu af miklum heilindum og peim er almennt umhugað um vellíðan og góðan námsárangur nemenda sinna. Oft veltir lítil púfa pungu hlassi og má telja líklegt að breyting á afstöðu til mats í págu náms geti haft víðtæk áhrif á próun skólastarfs sem miðar að skóla án aðgreiningar og umfram allt auðgar nám allra barna.

\section{Assessment in inclusive education}

Inclusive education has been subject to controversial reviews over the last decade and is riddled with uncertainty as to how it should be implemented. Key concepts in inclusive education are quality education, full participation, equal opportunities and democratic values. In Iceland a common understanding of the policy is that all students have educational opportunities in their home school, regardless of physical, mental or social abilities or cultural origin.

Contradictory definitions of the policy have, nonetheless, had an impact on teachers' views and beliefs. This is in part because difficulties have arisen in translating the concept of inclusive education. Increased awareness has emerged for the shared understanding of the epistemology base behind the policy for all stakeholders, within and outside the schools themselves. 
When meeting the needs of all pupils, teachers are key agents in differentiated teaching and instructions. Studies have, however, indicated that assessment has not been efficiently linked to differentiated instruction and assessment in Iceland. Assessment is seen as a comprehensive concept and its main purpose is to guide and motivate students towards further learning, inspire and promote metacognition.

The main purpose of assessment for learning is to evaluate students and use the information to have a positive effect on children's learning. It focuses on the students' abilities to further their own learning, by participating in both the process of learning and the assessment. This in turn, gives the child increased awareness of responsibility, eagerness to learn and fosters self-belief. Quality assessment can increase students' participation in their own learning and have a positive effect on growth mindset.

Individuals who view themselves from the perspective of a growth mindset, believe they have abilities to affect their learning process, by intuition and tenacity. Challenges are opportunities to learn from and grow and achievement is derived by working hard. With this in mind the challenge for teachers is to promote self-belief in all their students.

This research focused on how teachers in early education use assessment in inclusive education. The research took place in one municipality in Iceland, namely, Kópavogur. Four interviews with five participants were taken. One interview included two teachers who work in team teaching. The study aimed at understanding what kind of assessment teachers use within diverse groups of pupils in inclusive education. Teachers' understanding and views regarding the policy were explored, as well as gaining teachers' understanding of assessment and how they implement it with their pupils. The municipality's policy documents and school curriculum were reviewed and analyzed.

The main findings of this research imply that teachers have a positive view towards inclusive education but believe increased funding is required to implement its policies. Participants showed a divergent but sound understanding of the inclusive policy and their teaching methods are characterized by trying to meet the needs of all by using differentiated instructions. However, an inconsistency was found in their view of where students with disabilities are placed within the schools and an uncertainty as to who is considered responsible for those students' education. Participants were aware of the importance of using authentic assessment, both summative and formative assessment. Yet, there was an indication of misconceptions about the role of assessment for learning (i.e. formative assessment) and its widespread effect on students' learning.

Teachers are seen as the key agents in promoting inclusive education and meeting the needs of a diverse group of pupils. For that, a professional dialogue about education in general is needed within all schools which, in turn, promotes teachers' professionalism and competences.

Key words: Inclusive education, assessment, formative assessment, growth mindset.

\section{Um höfundana}

Auður Lilja Harðardóttir (audur@isaksskoli.is) er umsjónarkennari í Ísaksskóla. Hún lauk B.Ed.-prófi í kennslu yngri barna árið 2013 og meistaraprófi í kennslu yngri barna frá Menntavísindasviði Háskóla Íslands 2017. Dessi grein er byggð á meistaraprófsverkefni Auðar. 
Jóhanna Karlsdóttir (johannak@hi.is) er lektor í kennslu- og menntunarfræðum við Menntavísindasvið Háskóla Íslands. Hún lauk kennaraprófi frá Kennaraskóla Íslands árið 1972, framhaldsnámi í byrjendakennslu og myndmennt frá Danmarks Lærerhøjskole árið 1989 og M.Ed.-prófi í menntunarfræðum frá Kennaraháskóla Íslands árið 2001. Rannsóknir hennar beinast einkum að kennslufræði, menntun án aðgreiningar, fjölbreytileika nemenda, sögum kennara um menntun fyrir alla og árangursríkri kennslu.

\section{About the authors}

Auður Lilja Harðardóttir (audur@isaksskoli.is) is a teacher in the primary school Ísaksskóli in Reykjavík. She completed a B.Ed. degree in Teaching Young Children at the University of Iceland in 2013 and a master's degree in primary teaching from the Faculty of Teacher Education, University of Iceland in 2018. This article is based on her master's thesis.

Jóhanna Karlsdóttir (johannak@hi.is) is an Assistant Professor at the University of Iceland - School of Education. She graduated from Iceland Teacher College as a teacher in 1972, graduated in studies in elementary teaching from Denmark's University of Pedagogy in 1989 and earned an M.Ed. in Education from Iceland University of Education in 2001. Her main research focuses on pedagogy, inclusive education, learner diversity, and teachers' stories about inclusion and best practices.

\section{Heimildir}

Ainscow, M. (2005). Developing inclusive education systems: What are the levers for change? Journal of Educational Change, 6(2), 109-124. doi:10.1007/s10833-005-1298-4

Ainscow, M. (2008). Teaching for diversity:The next big challenge. Í F. M. Connelly, M. F. He og J.A. Phillion (ritstjórar), The SAGE handbook of curriculum and instruction (bls. 240-258). Los Angeles: Sage.

Ainscow, M., Booth, T. og Dyson, A. (2006). Improving schools, developing inclusion. New York: Routledge.

Ainscow, M., Dyson, A. og Weiner, S. (2013). From exclusion to inclusion:Ways of responding in schools to students with special educational needs. Manchester: Centre for Equity in Education, University of Manchester.

Ainscow, M. og Miles, S. (2008). Making education for all inclusive:Where next? Prospects, 38(1), 15-34. doi:10.1007/ s11125E008E9055E0

Arthur Morthens og Gretar L. Marinósson. (2002). Árangursríkt skólastarf og skóli fyrir alla: Opinber stefna um skilvirkan skóla án aðgreiningar. Grunnskólinn og kennarastarfið. Sótt af https://notendur.hi.is/ ingvars/namskeid/Grunnskolinn/Leidbeiningar/Skjol/skolianadgrein.htm

Banks, J. A. (2007). Diversity and citizenship education: Global perspectives. Indianapolis, IN: Jossey-Bass.

Black, P. og Wiliam, D. (1998a). Inside the black box. Phi Delta Kappan, 80(2), 139-148. Sótt af http://www. jstor.org/stable/20439383

Black, P. og Wiliam, D. (1998b). Assessment and classroom learning. Assessment in Education, 5(1), 7-72. doi:10.1080/0969595980050102

Boaler, J. (2016). Mathematical mindset: Unleashing students' potential through creative math, inspiring messages and innovative teaching. San Francisco: Jossey-Bass.

Booth, T. og Ainscow, M. (2002). Index for inclusion: Developing learning and participation in schools. Bristol: CSIE.

Braun,V. og Clarke,V. (2006). Using thematic analysis in psychology. Qualitative Research in Psychology, 3(2), 77-101. Sótt af http://eprints.uwe.ac.uk/11735/2/thematic_analysis_revised_-_final.pdf

Chappuis, J. og Chappuis, S. (2002). Understanding school assessment: A parent and community guide to helping students learn. Portland, OR: Assessment Training Institute. 
Dóra S. Bjarnason. (2012). Formáli að íslensku útgáfunni. Í D.L. Ferguson, G. Ralph, G. Meyer, J. Lester, C. Droege, H. Guðjónsdóttir, N. K. Sampson og J. Williams (ritstjórar), Nám fyrir alla: Undirbúningur, kennsla og mat i skóla margbreytileikans (bls. v-vii). Reykjavík: Háskólaútgáfan.

Dweck, C. S. (2010). Even geniuses work hard. Educational Leadership, 66(1), 16-20. Sótt af http:// web.a.ebscohost.com/ehost/detail/detail?sid=94266d71-760b-4ca0-af92-7a41b9366ac0\%40sessionmgr4010\&vid=0\&hid=4104\&bdata $=$ JnNpdGU9ZWhvc3QtbGl2ZQ== - AN=53491076\&db $=$ aph

Dweck, C. S. (2016). Mindset. The new psychologogy of success: How we can learn to fulfill our potential. New York: Ballantine Books.

Dysthe, O. (2008). The challenges of assessment in a new learning culture. Í A. Havnes og L. McDowell (ritstjórar), Balancing dilemmas in assessment and learning in contemporary education (bls. 15-28). New York: Routledge.

Earl, L. M. (2013). Assessment as learning: Using classroom assessment to maximize student learning (2. útgáfa). California: Sage.

Earl, L. M. og Katz, S. (2012). Getting to the core of learning: Using assessment for self-monitoring and self-regulation. Í M. M. C. Mok (ritstjóri), Self-directed learning oriented assessments in the Asia-Pacific (bls. 123-137). Dordrecht: Springer.

Erna Ingibjörg Pálsdóttir. (2011). Fjölbreyttar leiðir í námsmati: Að meta pað sem við viljum að nemendur laeri. Reykjavík: IĐNÚ.

European agency for special needs and inclusive education. (2017). Education for all in Iceland - External audit of the Icelandic system for inclusive education. Óðinsvé: Höfundur. Sótt af https://www.menntamalaraduneyti.is/ media/frettatengt2016/Final-report_External-Audit-of-the-Icelandic-System-for-Inclusive-Education.pdf

Guðmundur Heiðar Frímannsson, Rósa Eggertsdóttir og Rúnar Sigpórsson. (2013). Miðlarar menntunar, siðferðilegir vegvísar og fyrirmyndir.Viðtal við Trausta Dorsteinsson. Í Rúnar Sigpórsson, Guðmundur Heiðar Frímannsson og Rósa Eggertsdóttir (ritstjórar), Fagmennska í skólastarfi: Skrifað til heiðurs Trausta Dorsteinssyni (bls. 19-34). Reykjavík: Háskólaútgáfan.

Hermína Gunnpórsdóttir. (2010). Kennarinn í skóla án ađgreiningar:Áhrifavaldar á hugmyndir og skilning íslenskra og hollenskra grunnskólakennara. Rádstefnurit Netlu - Menntakvika 2010. Sótt af http://netla. hi.is/menntakvika2010/013.pdf

Hermína Gunnpórsdóttir. (2014). The teacher in an inclusive school: Exploring teachers' construction of their meaning and knowledge relating to their concepts and understanding of inclusive education (doktorsritgerð). Sótt af http:// hdl.handle.net/1946/19431

Hermína Gunnpórsdóttir og Dóra S. Bjarnason. (2014). Conflicts in teachers' professional practices and perspectives about inclusion in Icelandic compulsory schools. European Journal of Special Needs Education, 29(4), 491-504. doi:10.1080/08856257.2014.933543

Hermína Gunnpórsdóttir og Ingólfur Ásgeir Jóhannesson. (2014). Additional workload or a part of the job? Icelandic teachers' discourse on inclusive education. International Journal of Inclusive Education, 18(6), 580-600. doi:10.1080/13603116.2013.802027

Ingólfur Ásgeir Jóhannesson. (2006a). „Strong, independent, able to learn more ...": Inclusion and the construction of school students in Iceland as diagnosable subjects. Discourse: Studies in the Cultural Politics of Education, 27(1), 103-119. doi:10.1080/01596300500510328

Ingólfur Ásgeir Jóhannesson. (2006b). Different children - a tougher job: Icelandic teachers reflect on changes in their work. European Educational Research Journal, 5(2), 140-151. doi:10.2304/eerj.2006.5.2.140

Ingvar Sigurgeirsson. (1999). Námsmat byggt á traustum heimildum. Í Helgi Skúli Kjartansson, Hrafnhildur Ragnarsdóttir, Kristín Indriðadóttir og Ólafur J. Proppé (ritstjórar), Steinar í vörðu:Til heiðurs Durídi J. Kristjánsdóttur sjötugri (bls. 147-169). Reykjavík: Rannsóknarstofnun Kennaraháskóla Íslands.

Jóhanna Karlsdóttir og Hafdís Guðjónsdóttir. (2010). Hvernig látum við púsund blóm blómstra? Skipulag og framkvæmd stefnu um skóla án aðgreiningar. Rádstefnurit Netlu - Menntakvika 2010. Sótt af http:// netla.khi.is/menntakvika2010/016.pdf

Krisján Kristjánsson. (2007). Menntun, sjálfsproski og sjálfshvörf. Hugur, tímarit um heimspeki, 19(1), 121-133. Sótt af https://timarit.is/view_page_init.jsp?gegnirId=001062532 
Kristján Kristjánsson. (2008). „Vaxtarsjálf eða festusjálf“: Skiptir pað máli fyrir árangur og líðan nemenda? Skólavarðan, 3(8), 5-6. Sótt af https://timarit.is/view_page_init.jsp?pageId=6663496

Lichtman, M. (2013). Qualitative research in education: A user's guide (3. útgáfa). California: Sage.

Lög um grunnskóla nr. 91/2008.

Marsh, C. J. og Willis, G. (2003). Curriculum: Alternative approaches, ongoing issues (3. útgáfa). Upper Saddle River, NJ: Pearson.

Mennta- og menningarmálaráđuneytið. (2013). Aðalnámskrá grunnskóla 2011: Almennur hluti: Greinasvið 2013 (2. útgáfa með breytingum). Reykjavík: Höfundur.

Meyvant Pórólfsson, Ingvar Sigurgeirsson og Jóhanna Karlsdóttir. (2009). Tilgangur námsmats: Rannsókn á stefnumörkun grunnskóla. Netla - Veftímarit um uppeldi og menntun. Sótt af http://netla.hi.is/greinar/2009/007/06/

Moen,T. (2008). Inclusive education practice: Results of an empirical study. Scandinavian Journal of Educational Research, 52(1), 59-75. doi:10.1080/00313830701786628

Rúnar Sigpórsson. (2008). Mat í págu náms eða nám í págu mats. Samromd próf, kennsluhugmyndir kennara, kennsla og nám í náttúrufraði og íslensku i fjórum íslenskum grunnskólum (doktorsritgerð). Sótt af http://hdl. handle.net/1946/1973

Sapon-Shevin, M. (2007). Widening the circle:The power of inclusive classrooms. Boston: Beacon Press.

Sigríður Halldórsdóttir. (2016). Fyrirbærafræði sem rannsóknaraðferð. Í Sigríður Halldórsdóttir (ritstjóri), Handbók í aðferðafroði rannsókna (bls. 281-297). Akureyri: Háskólinn á Akureyri.

Stiggins, R., Arter, J. A., Chappuis, J. og Chappuis, S. (2004). Classroom assessment for student learning: Doing it right - using it well. Portland, OR: Assessment Training Institute.

Stiggins, R. og Chappuis, J. (2006). What a difference a word makes: Assessment for learning rather than assessment of learning helps students succeed. Journal of Staff Development, 27(1), 10-14. Sótt af http:// downloads.pearsonassessments.com/ati/downloads/What-a-difference-a-word-makes.pdf

Tetler, S. (2005). Tensions and dilemmas in the field of inclusive education. Í A. Gustavsson, J. Sandvik, R. Traustadóttir og J.Tössebro (ritstjórar), Resistance, reflection and change. Nordic Network on Disability Research (bls. 265-276). Lundur: Studentlitteratur.

Auður Lilja Harðardóttir og Jóhanna Karlsdóttir. (2019).

Námsmat á yngsta stigi í skóla án aðgreiningar.

Netla - Veftímarit um uppeldi og menntun. Menntavísindasvið Háskóla Íslands.

Sótt af http://netla.hi.is/serrit/2019/menntun_barna_leik_grunn/07.pdf

DOI: https://doi.org/10.24270/serritnetla.2019.39 